\title{
The disruptive power of legal biography: the life of Lord Phillimore - churchman and judge
}

Article

Accepted Version

Smith, C. (2020) The disruptive power of legal biography: the life of Lord Phillimore - churchman and judge. Journal of Legal History, 41 (2). pp. 164-185. ISSN 1744-0564 doi:

https://doi.org/10.1080/01440365.2020.1783607 Available at https://centaur.reading.ac.uk/91390/

It is advisable to refer to the publisher's version if you intend to cite from the work. See Guidance on citing.

To link to this article DOI: http://dx.doi.org/10.1080/01440365.2020.1783607

Publisher: Taylor \& Francis

All outputs in CentAUR are protected by Intellectual Property Rights law, including copyright law. Copyright and IPR is retained by the creators or other copyright holders. Terms and conditions for use of this material are defined in the End User Agreement.

www.reading.ac.uk/centaur

\section{CentAUR}


Central Archive at the University of Reading

Reading's research outputs online 


\title{
The Disruptive Power of Legal Biography: The Life of Lord Phillimore - Churchman and
}

Judge

\begin{abstract}
This article uses a biography of Lord Walter George Frank Phillimore, a prominent High Churchman and judge in the later nineteenth and early twentieth centuries, to explore the ability of legal biography to disrupt settled or uncritical readings of his comments on the nature of an established church in the case of Marshall v Graham (1907). In so doing it highlights the impact of the nineteenth century's legal and constitutional reforms upon High Churchmen and lawyers like Phillimore and examines the impact of his churchmanship upon his personal and professional life.
\end{abstract}

\section{Introduction}

Aston Cantlow and Wilmcote with Billesley Parochial Church Council v Wallbank, ${ }^{1}$ a 2003 decision of the house of lords concerning the status of parochial church councils under the Human Rights Act 1998 s.6, is not an obvious starting point for an essay on legal biography. ${ }^{2}$ In that case, however, several judges $^{3}$ cited a dictum by Walter Phillimore J (later Lord Phillimore) in Marshall v Graham, ${ }^{4}$ stating that:

A Church which is established is not thereby made a department of the state. The process of establishment means that the state has accepted the Church as the religious body in its opinion truly teaching the Christian faith, and given to it a certain legal position, and to its decrees, if rendered under certain legal conditions, certain civil sanctions. ${ }^{5}$

This was enormously helpful to judges considering the legal status of the Church of England and its constituent bodies, none of whom viewed it as being in any way contentious. Rather, they used it as an apt aphorism. The task of this essay is, through an examination of the life of Walter George Frank Phillimore, to challenge their assumptions, and to disrupt readings of Phillimore's dictum which numb the reader to its political and theological significance.

\section{Walter Phillimore's Judicial Career: Disrupting Assumptions}

\footnotetext{
${ }^{1}$ [2001] EWCA Civ. 713; [2003] UKHL 37.

${ }^{2}$ See Charlotte Smith, 'A very English affair: establishment and human rights in an organic constitution' in Peter Cane, Carolyn Evans and Zoe Robinson (eds.), Law and religion in theoretical and historical context, Cambridge, 2008, 157 - 185; Frank Meisel, 'The Aston Cantlow case: blots on English jurisprudence and the public/private law divide' [2004] Public Law 2; Augur Pearce, 'Aston Cantlow: Chancel Repairs and the Status of Church of England Institutions' 151 Law and Justice - Christian Law Review (2003) 163.

${ }^{3}$ Most notably [2003] UKHL 37, para. 61 per Lord Hope (who includes a direct quotation); para. 156 per Lord Roger (paraphrasing); and [2001] EWCA Civ. 713, para. 31, per Sir Andrew Morritt VC giving the judgment of the court of appeal (giving citation only as authority for proposition concerning the special constitutional status of the Church of England).

${ }^{4}$ [1907] 2 K.B. 112.

${ }^{5}$ Ibid. 126.
} 
Walter Phillimore, first Baron Phillimore, lived from 21 November 1845 until 13 March 1929. Following an illustrious career at Westminster School and Christ Church Oxford, he was called to the bar at Middle Temple in 1868. After developing a successful legal practice he was appointed as a justice of the king's bench division in December 1897 and, in the autumn of 1913, he was elevated to the court of appeal. Following his retirement, in 1916, he very regularly sat as a volunteer in the judicial committee of the house of lords, where his contributions in the fields of commercial and maritime law were apparently greatly valued, and in the judicial committee of the privy council, where his broad knowledge and adaptability were much appreciated in dealing with prize, Indian and colonial appeals. In 1918 he was appointed chairman of the naval prize tribunal under the Naval Prize Act of $1918 .{ }^{6}$

Despite evidence of an unimpeachable legal career one might, if familiar with the name of Phillimore, be forgiven for experiencing surprise at finding Walter Phillimore sitting as a judge of the king's bench division in 1907. That he ended his career as a judge was not surprising. It was, in the natural course of things, an eventuality almost to be expected. ${ }^{7} \mathrm{He}$ had been chancellor of the diocese of Lincoln, an ecclesiastical judge, since 1872, and a patent of precedence (akin to taking silk) had been conferred upon him in December of 1883. Plainly he was a man of some professional standing. He was, moreover, the son and grandson of distinguished judges and, as 'Jehu Junior' noted, it 'is useful for a barrister of eminence to have been born to a Judge; if only because a Lord Chancellor, when beset by newspaper criticism until he is in doubt whither he shall turn to fill a judicial gap, is able to select him as being of judicial caste'. ${ }^{8}$ Further, Phillimore three times failed to win a parliamentary seat in the Liberal interest, ${ }^{9}$ had not taken a large role in national politics, and was, apparently, neither suited to the atmosphere of the house of commons nor gifted as a platform speaker. His rather 'pedantic' style was apt to irritate the members of the house of lords when he took his seat there. ${ }^{10}$

\footnotetext{
${ }^{6}$ See the entry for Walter Phillimore by Sankey, revised by Hugh Mooney (2004) in the Oxford Dictionary of National Biography <www.oxforddnb.com/view/10.1093/ref:odnb/9780198614128.001.0001/odnb9780198614128-e-35511?rskey $=$ Yc8XD5\&result $=9>$ (accessed 26 November 2019). See also 'A Great International Jurist' in The Times, 14 March 1929, 21; Law Journal, 16 March 1929, 193; Also newspaper cuttings accessed at the Hampshire Archives in Winchester: 155M88/F17/3: Letter to the Editor of The Times from A. Majid, President of the Islamic Society on the Death of 'Lord Phillimore' and 115M88/Z8/16: 'Lord Phillimore' from 'Friend' The Guardian, 22 March 1929. For his judgments in the house of lords and privy council see Walter G.F. Phillimore, Judgments delivered in the Privy Council, 1915-1928 (Middle Temple Library, London) and Walter G.F. Phillimore, Judgments delivered in the House of Lords, 1919-1928 (Middle Temple Library, London).

${ }^{7}$ On judicial appointments following the Judicature Act 1873 see Patrick Polden, 'Mingling the Waters', 61 Cambridge Law Journal (2002) 575.

${ }^{8}$ Hampshire Record Office (Winchester) 155M88/F17/1 and 2: Vanity Fair, London, 24 Nov. 1898, 353 'The Hon. George Frank Phillimore, Bart, DCL' by Jehu Junior.

${ }^{9}$ For election materials see British Library (London - hereafter BL) ADD MS 44279 fos. 69-70, 168ff, 219-221.

${ }^{10}$ The Times, 14 March 1929, 21. Though he Church Times wrote that, 'his legal knowledge and deep acquaintance alike with ecclesiastical law and with the whole history of the religions movements in nineteenthcentury England made him an effective and impressive pleader for the [high church] cause' in the church assembly. 'Death of Lord Phillimore: A Faithful Catholic and a Great Lawyer' Church Times, 15 March 1929, 316.
} 
Walter Phillimore himself seems to have felt the force of the call of the bench, writing to Gladstone:

Having almost given up the idea of again trying for Parliament, the judicial career was the only change of life left to me; and it seemed to me that it would be a pity to continue all my days as an advocate, and I had it borne in upon me that I had some vocation to be a judge. And now that I am a judge I see even more than before how important the work is, and while I wonder rather that I took it with so light a heart, I am glad to be doing it. ${ }^{11}$

It was, nevertheless, surprising to find him sitting in the king's bench division. The name of Phillimore had, after all, long been associated with civil law, with doctors commons, and with the ecclesiastical and admiralty courts and international law. Both Walter's father, Sir Robert Phillimore, and his grandfather, Dr Joseph Phillimore, had been eminent practitioners and judges in the civilian courts, and it was more naturally to be expected that Walter would follow them there. Perhaps for this reason, the author of his entry in the Oxford Dictionary of National Biography states that his appointment to the then queen's bench division occasioned 'some surprise', and that his later elevation to the court of appeal was 'a surprise', or, in the words of The Times, 'not altogether expected'. ${ }^{12}$

Such surprise was, prima facie, justified. Phillimore had rarely appeared in the common law courts and he was best known in the ecclesiastical courts, where he acted as defence counsel for the English Church Union ${ }^{13}$ in many of the most prominent cases against advanced high church ornaments, ceremonial, liturgy and ritual. Latterly, as evangelicals and advanced high churchmen largely ceased to fight their battles through the medium of litigation, ${ }^{14}$ he practiced extensively in the court of admiralty, where he was one of the leaders of the bar. ${ }^{15}$ Beyond this, he was known as an eminent international lawyer who would, in the turbulent years ahead, play a significant role in the formation of the League of Nations. ${ }^{16}$ None of this, however, obviously fitted him for a judicial role in the queen's bench division. Nor was the explanation to be found in the political motivations which so often drove Lord

\footnotetext{
${ }^{11}$ BL ADD MS 44279 fos. 222-223 (10 December 1897).

1214 March 1929, 21.

${ }^{13}$ A campaigning body advocating for and defending high church principles, and defending clergy prosecuted for their adoption of High Church liturgical practices. See Rev. G. Bayfield Roberts, The History of the English Church Union, 1859 - 1894, London, 1895. On the place and context of the advanced high church party - or ritualists - in the nineteenth century Church of England see Bethany Tanis, 'Diverging Paths: Fin-de-Siècle Britishness and the Oxford Movement' 77(3) Anglican and Episcopal History (2008) 287; K. Theodore Hoppen, The Mid-Victorian Generation, 1846 - 1886, Oxford, 2006, ch. 12; John Maiden, National Religion and the Prayer Book, Woodbridge, 2001, introduction; Stewart J. Brown and Peter B. Nockles (eds.), The Oxford Movement : Europe and the Wider World 1830-1930, Cambridge, 2012, introduction; Peter Benedict Nockles, The Oxford Movement in Context: Anglican High Churchmanship, 1760-1857, Cambridge, 1994, especially ch. 4 and 209-223.

${ }^{14}$ See Royal Commission on Ecclesiastical Discipline 1906 (Cd 3040, 1906) - especially chs. 9 and 10.

${ }^{15}$ See Law Journal, 4 December 1897, 591, 'Obiter Dicta'; Vanity Fair, 24 Nov. 1898, 353.

${ }^{16}$ Ibid. Also, The Times, 14 March 1929, 21; The Guardian, 22 March 1929. See Walter George Frank Phillimore, Three Centuries of Treaties of Peace and their Teaching, London, 1919; Walter George Frank Phillimore, Schemes for Maintaining General Peace, London, 1920.
} 
Halsbury's judicial appointments. ${ }^{17}$ Phillimore, insofar as he had been active in politics, had always been a staunch Gladstonian Liberal, causing 'Jehu Junior' to comment with characteristically biting satire:

Sir Walter Phillimore had more virtues than that of an honoured name: he was himself a learned, honourable, and courteous gentleman who had long had a fine practice in the Courts of Admiralty. Accordingly he was chosen to preside over a Common Law Court, before which no Admiralty case can come: which was something of a surprise; for an alleged ignorance of the Common Law is only excusable in a Judge when he has been a politician, or has done service to his Party. Now Sir Walter was - a Judge has no Politics - a philosophic and philanthropic Radical of the ancient type... ${ }^{18}$

Yet, Phillimore's appointment was not as odd as it at first appeared. The Law Journal felt that 'no exception' could be taken to it, asserting:

Sir Walter Phillimore has for several years past been the leading advocate in the Admiralty Court, and has acquired a wide reputation as an ecclesiastical and international lawyer. If this were the whole of his claim to a seat on the Bench it might be said he was too much a specialist to make a successful judge of the Queen's Bench Division; but his legal knowledge is known to extend beyond the fields in which he has more particularly worked, while the manner in which he has discharged his duties as a Commissioner of Assize on the North-Eastern Circuit is calculated to remove any fear which may be entertained as to his ability to perform the general duties of a common-law judge. ${ }^{19}$

There was, at least in some quarters, a quiet confidence that his field of wider expertise and previous experience as a commissioner of assize fitted Phillimore for office. Nor, it seems, was this entirely misplaced. Though 'A Friend' remembered 'hostile rumours during his earlier years in the king's bench division', ${ }^{20}$ and though The Times commented on his 'comparative failure as a Judge of first instance', and on undue severity towards prisoners charged with sexual offences, and weaknesses in his forensic judgment and handling of juries, ${ }^{21}$ most admitted that 'as time went on his judgment became sounder, his horizon wider, and his prejudices or predilections less operative'. ${ }^{22}$ Further, whatever doubts attached to his ability to deal with facts, his abilities as a lawyer were never in question. Even within a year of his appointment to the queen's bench division the barbed pen of 'Jehu Junior' had called him an 'ornament of his profession, who has deserved his success', remarking:

... though he was only made a Judge last year, he has shown himself so firm and polite, and so painstaking as to justify the Lord High Chancellor in his selection. More than this, he has surprised the Bar with his unknown acquaintance with the Common Law of England: which is

\footnotetext{
${ }^{17}$ Robert Stevens, Law and Politics: The House of Lords as a Judicial Body, 1806 - 1976, London, $1979,85$.

18 Also Law Journal, 4 Dec. 1897, 591, 'Obiter Dicta', reflecting positively on the appointment's non-political character.

${ }^{19}$ Ibid.

${ }^{20}$ The Guardian, 22 March 1929.

${ }^{21}$ The Times, 14 March 1929, 21.

${ }^{22}$ Ibid.
} 
only less than one or two of his older brethren. It is not too much to say that before he had sat into his third term he was recognised as one of the best of our puisne Judges. ${ }^{23}$

Upon his death tributes were paid to his learning and ability, to his use of language, and to the fact that he "excelled in the difficult labour of evolving clearness and consistency out of a jumble of confused and apparently contradictory Acts of Parliament'. ${ }^{24}$

Given his acknowledged legal ability, and his subsequent judicial activities, Phillimore's later appointment to the court of appeal should not have been unexpected. His 'special services as Judge in Bankruptcy' had 'entitled him to this promotion above some of his seniors in office'. ${ }^{25}$ The fact that, when Hamilton (Lord Sumner) was promoted to the house of lords, only Ridley, Channell and Darling were senior to Phillimore on the bench undoubtedly strengthened his claim. None had proved themselves to be judges of distinction. ${ }^{26}$

Walter Phillimore fully justified his appointment to the court of appeal and, whether sitting there, or later as a volunteer in the judicial committee of the house of lords or the judicial committee of the privy council, he was freed of the limitations which had, perhaps, mitigated his success as a puisne judge. In the court of appeal, The Times wrote, his 'limitations faded and his qualities as a profound lawyer became more apparent', and 'he added distinction to a particularly strong Court'. Upon taking his seat in the house of lords, it asserted, he 'took his place among the great lawyers of his generation'. ${ }^{27}$ To the Law Journal he was 'a great common law judge'. ${ }^{28}$

There were, in fact, compelling reasons why Phillimore should have looked for preferment in the secular courts, rather than in the ecclesiastical and admiralty courts. Not the least of these was the fate suffered by them in the nineteenth century. The right of audience of the high court of admiralty were liberalised by the High Court of Admiralty Act 1859, even before its absorption into the probate, divorce and admiralty division of the new high court in $1875 .{ }^{29}$ Meanwhile, by the middle of the nineteenth century, the ecclesiastical courts had been stripped of their testamentary and matrimonial business, and of their jurisdiction in defamation, ${ }^{30}$ and, by the end of the century, the appetite for

\footnotetext{
${ }^{23}$ Vanity Fair, London, 24 Nov. 1898, 353.

${ }^{24}$ The Guardian, 22 March 1929.

${ }^{25}$ Law Journal, 18 Oct. 1913, 580, 'Obiter Dicta'.

${ }^{26}$ Law Journal, 18 Oct. 1913, 591, 'Lord Justice Phillimore'.

27 The Times, 14 March 1929, 21.

${ }^{28}$ Law Journal, 16 March 1929, 193.

${ }^{29}$ Patrick Polden, 'The Civilian Courts and the Probate, Divorce, and Admiralty Division' 692 - 756 in William Cornish et al, The Oxford History of the Laws of England, vol. X, 1820 - 1914: English Legal System, Oxford, 2010.

${ }^{30}$ A process begun by Brougham. See generally Brian Gerald Hutton, 'The Reform of the Testamentary Jurisdiction of the Ecclesiastical Courts, 1830-1857', dissertation submitted for the degree of Doctor of Philosophy, Brunel University, Uxbridge, 2002; Michael Lobban, 'Henry Brougham and Law Reform' 115 (246) English Historical Review (2000) 1184-1215; also R.B. Outhwaite, The Rise and Decline of the English Ecclesiastical Courts, 1500 - 1860, Cambridge, 2007 - especially chs. $9-15$.
} 
ecclesiastical litigation in matters of worship and doctrine had waned. There was, in short, little business left there to the civilian profession and doctors commons had closed its doors. ${ }^{31}$

Phillimore's personal faith, too, may have limited the availability to him of preferment in the ecclesiastical courts, particularly in an era of heightened theological tensions and party strife within the Church of England. All of the Phillimore lawyers were 'High Church men with a pronounced ecclesiastical trait', ${ }^{32}$ but Walter allied himself with the advanced anglo-catholics, or ritualists, who sought to reform the worship of the church, and to introduce (or reintroduce) practices and ornaments redolent of its catholic past. ${ }^{33} \mathrm{He}$ was a campaigning member of their representative body, the English Church Union, served as its lay president and vice president towards the end of his life, and was the dominant force and long serving chair of its legal committee. Often appearing as counsel for its members in the great ritual cases of the era, ${ }^{34}$ he also represented the advanced high church in evidence to the late nineteenth and early twentieth century commissions on ecclesiastical courts and discipline, ${ }^{35}$ as well as being a prominent anglo-catholic member of the church assembly commission which reported on ecclesiastical courts in $1926 .^{36}$

Phillimore 'never concealed his view of Church questions, nor failed in his loyalty to the Catholic Faith', ${ }^{37}$ but, outside of the friendly pages of the Church Times, this assessment was not entirely favourable. The high church movement was viewed with ambivalence in the later nineteenth century, and into the twentieth century. Its tractarian or Oxford movement forebears were, to some extent, rehabilitated and lauded as the authors of spiritual revival and renewal in the church of England, ${ }^{38}$ and the more moderate high church innovations/revivals in public worship gained increasing acceptance. Yet there remained, in some quarters, a powerful antipathy to high church theology and

\footnotetext{
${ }^{31}$ See generally George Drewry Squibb, Doctors' Commons: A History of the College of Advocates and Doctors of Law, Oxford, 1977.

32 The Times, 14 March 1929, 21.

${ }^{33}$ For the distinction between the tractarians of Robert Phillimore's day versus the Ritualists of Walter Phillimore's era see Pusey House (Oxford): Halifax Papers: Priscilla Sellon to Charles Lindley Wood (14 June 1875).

${ }^{34}$ All Phillimore's obituaries speak of this, but see especially Church Times, 15 March 1929, 316 and 307. For the extent and longevity of his involvement in the advanced high church cause, and for his intimacy with many of its leading lights see BL ADD MS 44279 fos. 118-121, 124-125, 133-134, 139-141, 157-160, 203-208; Letters from Walter Phillimore to Lord Halifax 1875 - 1912, copies of letters of Lord Halifax to Walter Phillimore 1893 - 1928 and 1875 - 1928 at Borthwick Institute (hereafter Borthwick -York) A4.212. ${ }^{35}$ Evidence to 1883 Royal Commission on Ecclesiastical Courts (C.3760), 24 June 1881, 1 July 1881 1199ff; evidence to 1906 Royal Commission on Ecclesiastical Discipline (Cd 3069) vol. I, 3459 - 3592 and 4829 5088, 14 July 1904, 28 July 1904.

${ }^{36}$ Report of the Ecclesiastical Courts Commission 1926 (CA 200).

${ }^{37}$ Church Times, 15 March 1929, 316.

38 Bethany Tanis, 'Diverging Paths'.
} 
liturgical practice as being antithetical to the maintenance of a protestant national identity and spirit, which underpinned Britain's prosperity and success. ${ }^{39}$

Such ambivalence, and a slight squeamishness about religious enthusiasm, were evident in tributes to Phillimore upon his death. The Church Times, not unexpectedly given its high church sympathies and ecclesiastical focus, called him a 'Faithful Catholic'. ${ }^{40}$ The Times, however, preferred a non-partisan and more general encomium to the effect that his 'life was a devotion to ideals of high thinking and of service to God and man'. ${ }^{41}$ Similarly, a 'Friend' described him as 'emphatically a Christian gentleman', but he was frustrated that there were many people 'who have known Lord Phillimore chiefly or solely in his Churchmanship'. Such people, he argued, knew 'only a small part of him'. Further, while he emphasised that, Phillimore's 'politics were Christian', he also asserted that this was not in the 'perverted sense which justifies persecution'. Rather, their Christian character was found 'in the sense of a conviction that every political right or privilege must be judged by the highest standard of equity and morality'. ${ }^{42}$ Several times, the impact of Phillimore's faith upon his professional conduct was alluded to negatively. A 'Friend', for example, admitted 'that stories of harshness, and of insufficient distinction between morality and law, might have some foundation'. ${ }^{43}$ Damning his early judicial career with faint praise, The Times wrote that there was 'no question of his capacity, in point learning... His comparative failure as a Judge of first instance lay rather in the sphere of the man of the world. Like other deeply religious men... he was prone to undue severity to convicted prisoners, especially in sexual offences'. ${ }^{44}$

If deep religious faith was not an unmixed blessing in the person of a judge, militant and openly stated high church sympathies were even more of a hindrance to Phillimore's advancement as an ecclesiastical lawyer. So, displaying the mixture of emotions and sentiments which Phillimore's adherence to the advanced anglo-catholic cause provoked, a 'Friend' opined that:

As an ecclesiastical lawyer he did not attain quite the first rank. He was limited by conscience. An immovable conviction of genuinely religious character tied him to a position in which he was liable to all the temptations of the partisan, and to some corresponding disabilities. His career may be said, without exaggeration, to have been wrapped up with the English Church Union. He never appeared to regret this limitation. He knew that he could do good service by accepting it, and was content to serve. It meant serving with men who were in no way his equals, except in fervour of faith and devotion, and who must sometimes have sorely tried his patience. ${ }^{45}$

\footnotetext{
${ }^{39}$ For a discussion of this in relation to the debate about revision of the Book of Common Prayer, a project in which Phillimore was involved, see generally John Maiden, National Religion.

${ }^{40}$ Church Times, 15 March 1929, 316.

${ }^{41}$ The Times, 14 March 1929, 21.

${ }^{42}$ The Guardian, 22 March 1929).

${ }^{43}$ Ibid.

${ }^{44}$ The Times, 14 March 1929, 21.

${ }^{45}$ The Guardian, 22 March 1929.
} 
Deeply held high church sympathies also explained why Phillimore was appointed to the queen's bench division, rather than to the probate, divorce and admiralty division where he might have more naturally found his home. Hs faith precluded him, as a matter of conscience, from presiding over divorce cases. For this reason he had not accepted briefs in divorce cases, thereby making 'a willing sacrifice of the large income which he could have made' by accepting such business. ${ }^{46} \mathrm{He}$ was, however, willing, when on circuit or presiding as vacation judge, to pronounce decrees absolute to petitioners for divorce. ${ }^{47}$ This may have been because he had 'too much respect for the president to decline to do as his predecessors have done before him'. ${ }^{48}$ It might also have reflected his character as a Gladstonian Liberal who, though remaining unchanged in his moral convictions, showed his liberalism 'in patient adjustment to the prevailing influence' ${ }^{49}$ Several of obituaries, however, asserted that, in doing so, he nevertheless stated his objection..$^{50} \mathrm{He}$ also, perhaps, told the parties that they remained married in the eyes of God; ${ }^{51}$ a course of action would have been consistent with his privately expressed difficulties in relation to the right treatment of persons who had entered marriages which, though legal as a matter of secular law, contravened the law of the church. ${ }^{52}$ Phillimore described the right treatment of such individuals as 'one of the most difficult' questions of which he knew. ${ }^{53} \mathrm{He}$ was, as he wrote privately, as 'strong against the lawfulness of such marriages as any one'. He openly acknowledged, however, his uneasiness with the pastoral consequences. Reflecting upon some clerics' determination to refuse such persons holy communion, ${ }^{54}$ he commented that 'when it comes to people... marrying in ignorance of the Church's law and in good faith, perhaps having children, it is a horrendous thing to compel them to separate, and an equally horrendous thing to refuse them not separated the Sacraments'. ${ }^{55}$ Writing again, in 1918, he noted 'that further consideration from the point of view of the care and pastoral discipline of souls is required in dealing with persons who are living in the married state having gone through the form of marriage de facto, though according to Catholic teaching not de jure'.$^{56}$

\footnotetext{
${ }^{46}$ Ibid. Though he had, on behalf of the Queen's Proctor, acted as counsel in the notorious case of Crawford $\mathrm{v}$ Crawford and Dilke (1886) 11 P.D. 150 - not, it seems, a happy or successful episode in Phillimore's practice. See The Times, 14 March 1929, 21. For his refusal to act in divorce cases see Law Journal, 16 March 1929, 193 and 23 March 1929, 220. Note that his father, Sir Robert Phillimore, also a high churchman, had presided over the probate, divorce and admiralty division from its creation until his retirement in 1883, See Norman Doe's entry for Robert Phillimore in the Oxford Dictionary of National Biography $<$ https://www.oxforddnb.com/view/10.1093/ref:odnb/9780198614128.001.0001/odnb-9780198614128-e22138? rskey=R61Imc\&result $=8>$ (accessed 3 April 2020).

${ }^{47}$ Law Journal, 23 March 1929, 220; The Guardian, 22 March 1929; Church Times, 15 March 1929, 316.

${ }^{48}$ Vanity Fair, 24 Nov. 1898, 353.

${ }^{49}$ The Guardian 22 March 1929.

${ }^{50}$ Vanity Fair, 24 Nov. 1898, 353.

${ }^{51}$ Church Times, 15 March 1929, 316; The Guardian, 22 March 1929. Apparently, this provoked hostility in the press.

${ }_{52}$ Most significantly in the case of remarriage after divorce and marriage of a deceased wife's sister.

${ }^{53}$ Walter Phillimore to Lord Halifax, Borthwick: A4.212: (3 Feb. 13 1909).

${ }^{54}$ On the basis that they were 'notorious evil livers' barred by canon law.

${ }^{55}$ Walter Phillimore to Lord Halifax, Borthwick: A4.212 (13 Feb. 1909).

${ }^{56}$ Ibid. (3 July 1918).
} 
Phillimore's concern for the pastoral care of individual souls was at odds with his ambitions for the interests and autonomy of the church. He was adamant in asserting 'that the State cannot dictate to the Church the terms on which she is to receive communicants to the altar', but he regretted the Church of England's 'inelasticity' in such matters, and its inability to regularise such marriages canonically through the use of dispensations. He also hesitated 'to put individual priests in the position of having for conscience sake to disobey their Bishops [if they condoned the secular law of marriage] and suffer state penalties'. ${ }^{57}$ Like Chancellor Dibdin before him, ${ }^{58}$ he keenly felt the difficulty of saying 'to a couple married under the law of a professedly Christian state that they are notorious evil livers'. ${ }^{59}$

What emerges, then, is a more complex picture than one might otherwise have been tempted to draw. The resulting portrait is of a man who, though by lineage and disposition a doyen of the civilian bar, was propelled by the consequences of the judicature reforms of the nineteenth century into the secular judiciary. The barrister whose whole practice had been in the civilian courts was, by force of individual conscience precluded from accepting the more obvious path to preferment in the High Court, finding a place in the queen's bench division, rather than in the 'court of wrecks'. Once safely embarked upon a judicial career, he defied the expectations of some to become 'one of the great lawyers of his generation'. Further, in his treatment of persons who had entered into marriages which were legal in secular law but canonically irregular, Phillimore also defied expectation. Banished is the picture of the inflexible anglo-catholic partisan who forewent professional largesse on a point of moral principle. In its place is the portrait of a man who, though convicted in his defence of the liberty of the church to determine whom it admitted to its sacraments, freely admitted to the difficulty of the resulting pastoral dilemmas, and hesitated to condemn those who had acted in conformity with secular law.

\section{Contextualising Phillimore's Dictum in Marshall v Graham: Disrupting Preconceptions}

An exploration of Phillimore's life enables us to discard easy stereotypes about high church zealots, ${ }^{60}$ revealing a picture of a man who was zealous, but who was sharply aware of the consequences of his beliefs, and willing in practice to seek an accommodation. It also casts into sharp relief the consequences, for men like Phillimore, of the legal reforms of the nineteenth and twentieth centuries. Above all, it provides a context for Phillimore's famous dictum, which should alert us to its potential theological and political significance, even without considering the differing standards of judicial

\footnotetext{
${ }^{57}$ Ibid. (23 June 1912).

${ }^{58}$ Banister v Thompson [1908] P. 362, 391.

${ }^{59}$ Walter Phillimore to Lord Halifax, Borthwick: A4.212 (23 June 1912).

${ }^{60}$ Perhaps best typified by those Ritualists who endured imprisonment for contempt rather than obey the orders of a court the authority of which they did not recognise. See the story of Arthur Tooth in Bernard Palmer, Reverend Rebels: Five Victorian Clerics and Their Fight Against Authority, London, 1993. For Phillimore's role see e.g. Letters from Walter Phillimore to Lord Halifax 1875 - 1912 - Borthwick: A4.212 (29 Sept. 1882), and BL ADD MS 44789 fos. 203-208 (15 June 1888).
} 
conduct which were applicable in 1907. ${ }^{61}$ Times and expectations were changing, and the degree of judicial impartiality and detachment from moral judgment expected of contemporary judges, was developing, but it had not yet fully developed. ${ }^{62}$

Suspicions, that Phillimore's dictum regarding the status of as established church is best understood within its religious and political context, and that he was motivated by considerations other than the strict demands of the case before him, are prompted by an awareness that neither of the judges sitting with him ${ }^{63}$ felt compelled to make similar statements. For them the question was simply whether or not Ascension Day was a day wholly set apart for the purposes of religious observance. ${ }^{64}$ Phillimore, too, accepted that this was the key question, but he then tellingly announced:

I wish to say a few words with respect to the argument of counsel for the respondent that the Church of England is not a body which has set apart any day for religious observance. ${ }^{65}$ That argument seems to me to be in part based upon a misapprehension of what the Catholic doctrine, whether Roman or Anglican, is as to religious observance. It is in part based upon an erroneous view of what establishment by law means. ${ }^{66}$

Phillimore was 'rather impatient of half knowledge in any region of thought, and very much inclined to snub its public manifestations'. He also welcomed 'a really good excuse for displaying knowledge'. ${ }^{67}$ But in making this announcement, and despite expressly disclaiming any temptation to treat on questions of theology of history, ${ }^{68}$ he was making a deliberate decision to state deeply held political and theological convictions, and to bring into the courtroom a campaign for ecclesiastical and constitutional law reform which he had long waged outside of it. He did so in response to argument by counsel, that the Church of England as a religious body had never set aside days wholly for religious

\footnotetext{
${ }^{61}$ Lord Selborne (another prominent high church lawyer) was horrified by the implication that his actions would be influenced by any other than purely legal considerations. See Selborne to Pusey (19 Feb. 1877) Lambeth Palace Library (hereafter LPL - London), MS 1866, fol. 235. Judges did, however, make moral assertions which would now be deemed inappropriate. See the unreported remarks of Kekewich J regarding the 'deterioration of moral character' caused by religious conversion - per adverse comment at The Church Times, 4 Feb. 1887, 79 re Allcard v Skinner (1887) 36 Ch. D. 145. See also Constantinidi v Constantinidi [1905] P. 253, 278 per Stirling LJ; Upfill v Wright [1911] 1 K.B. 506, 510 per Darling J. For analysis of changing judicial conduct and behaviour with regards to such statements see Sir James Munby, 'Law, Morality and Religion in the Family Courts' 16 Ecclesiastical Law Journal (2014) 131.

${ }^{62}$ For developing standards of professional conduct and impartiality see Michael Lobban, 'The Politics of English Law in the Nineteenth Century' 102-137 in Paul Brand and Joshua Getzler (eds.), Judges and Judging in the History of the Common Law and the Civil Law from Antiquity to Modern Times, Cambridge, 2012. Phillimore's pronouncements on the effects in God's eyes of secular divorce were said to have provoked 'a shriek of horror from the press' (The Church Times, 15 March 1929, 31) - indicating the declining acceptability of such remarks.

${ }^{63}$ Alverstone LCJ and Darling J.

${ }^{64}$ [1907] 2 K.B. 112, 121-122. Though both (Alverstone at 124 and Darling at 125) took pains in passing to refute the magistrates' assertion that a father who was irregular in his church attendance could not be considered a member of the Church of England.

${ }^{65}$ Ibid. 119.

${ }^{66}$ Ibid. 126.

${ }^{67}$ The Guardian, 22 March 1929.

${ }^{68}$ [1907] 2 K.B. $112,126$.
} 
observance, but rather that any such days had been set apart by statute. ${ }^{69}$ This cut to the heart of the nineteenth century high church revival, and to the campaigning activities of the English Church Union to which Phillimore had dedicated much of his life.

If the constitutional relationship between the Church of England and the state of England expressed by establishment conferred upon the church two sources of identity, as both a national religious institution and a spiritual body, then the essence of the high church revival was to grant the church a renewed sense of itself as a spiritual body, the spiritual authority and claims of which were derived from its identity as part of the Universal Church of Christ, from its character as the recipient of a divine commission, and as a repository of divine truth. ${ }^{70}$ The revival rejected the "whole domination of the law over every part of the Church of England' ${ }^{71}$ and, reacting to the perceived apostasy ${ }^{72}$ and inconstancy of a state which was rapidly embracing constitutional and social changes which unravelled the legal and ideological remnants of the confessional state, emphasised the Church's spiritual claims, identity and autonomy. Thus, in the first of the Tracts for the Times for which the High Church Oxford Movement was most famous, John Henry Newman cried:

I fear we have neglected the real ground upon which our authority is built, - our APOSTOLICAL DESCENT.

We have been born, not of blood, nor of the will of the flesh, nor of the will of man, but of God. The Lord JESUS CHRIST gave His Spirit to His Apostles; they in turn laid their hands upon those who would succeed them; and these again on others; and so the sacred gift has been handed down to our present Bishops... ${ }^{73}$

Phillimore, a true son and heir of the high church revival, consistently rejected the denial or neglect of the church's spiritual character, and its characterisation as a creature of statute. His dictum is best understood in the context of a relentless assertion, in church congress, in pamphlets, in evidence to various commissions, and in the house of lords, of the spiritual claims and identity of the Church of England. It was echoed in his other statements on the nature of establishment and established churches. In 1919, for example, he told the house of lords:

It is not that the law or the State or Parliament makes the Church. A man-made Church or a man-made religion must come to nought. ... The theory is that Parliament finds the Church already in existence, claiming its commission from its divine Founder, and, finding it, elects to

\footnotetext{
69 Ibid. per Danckwerts KC at 119.

${ }^{70}$ Brown and Nockles (eds.), The Oxford Movement : Europe and the Wider World, introduction; T.L. Harris, 'The Conception of Authority in the Oxford Movement' 3(2) Church History (1934), 115; Nockles, The Oxford Movement in Context; O. Chadwick, The Spirit of the Oxford Movement, Cambridge, 1990; J. S. Reed, Glorious Battle: The Cultural Politics of Victorian Anglo-Catholicism, Nashville, 1996; R. W. Church, The Oxford Movement: Twelve Years, 1833-1845, London, 1900.

${ }^{71}$ Bonamy Price, 'The Church of England,' Contemporary Review, vol. 10 (1869) 162.

72 The title of John Keble's famous assize sermon of 14 July 1833, which is often identified as launching the Oxford Movement, was entitled 'National Apostasy' < http://anglicanhistory.org/keble/keble1.html>.

${ }^{73}$ J. H. Newman, Thoughts on the Ministerial Commission, 2 < http://anglicanhistory.org/tracts/tract1.html >.
} 
make it secure in its temporal position. It makes it secure either out of genuine respect for the Christian religion and the belief that it is best taught and embodied in the Church, and the Church has the commission to teach it, or, which is a lower point of view, that which would have been taken by some eighteenth century Divines, because it regards the Church as an important organ of civilisation. ${ }^{74}$

The established church could not be 'made a department of the state' since the state took the church, which derived its authority from Christ, as it found it, according to it certain temporal advantages either from motivations of faith, or because such faith was a useful tool in the creation of civilised subjects. ${ }^{75}$

Nor could the state change the doctrinal standards of an established church, or meddle with its spiritual character. As Phillimore had asserted nearly fifty years earlier, 'having once established [the church], the State cannot afterwards alter or remodel its doctrines, or necessary rites of discipline, without destroying the ground of faith on which the whole body rests, and rendering the remodelled Church a mere creature of man and of civil law, without claim to Divine origin' ${ }^{76}$

Or again:

When the State establishes a Church, it does not create a new Church and a new religion, but it takes an existing Church and religion and establishes them. Consequently, anything that the State by virtue of the establishment may do to that Church, must be such as will not injure the foundations of the Church, such, that is, as will not contravene its essential doctrine and discipline; for otherwise the Church, being compelled to change its doctrine and discipline, would become a new Church, and would be not so much established as created by the State. ${ }^{77}$

The state could not interfere in the doctrine and discipline of the church without destroying the claims to divine authority upon which its establishment rested.

The role of the crown as both secular head of state and supreme governor of the Church of England was one of the clearest specific manifestations of establishment, and of the duality created by it between the church's spiritual and temporal identities. Here, too, Phillimore consistently contested the nature of establishment. Historically, the role of the crown was defended by reference to the 'quasispiritual' character of the monarch - the idea that 'the person of the Sovereign [was] religious, and that the conferring of the Crown upon him is sacramental' ${ }^{78}$ Phillimore, however, rejected this as 'a compound of pagan practices, principles of despotism, an overstraining of the feudal system, and a false

\footnotetext{
${ }^{74}$ Parliamentary Debates, series 5, vol. 35, col. 61, 1 July 1919 (House of Lords) concerning the Church Assembly (Powers) Bill 1919.

${ }^{75}$ A popular argument at the time. In his 1907 dictum of Phillimore speaks only of claims to truth rather than utility.

${ }^{76}$ Reports of the Proceedings of Church Congress (1876) 364.

${ }^{77}$ Walter G.F. Phillimore, The Government of the Church in Relation to the State and the Laity, London, 1879 , 11.

${ }^{78}$ Reports of the Proceedings of Church Congress (1876) 367. See also Earl Nelson Reports of the Proceedings of Church Congress (1882) 201.
} 
analogy from Jewish history'. ${ }^{79}$ Even if this were not so, the powers of the crown had largely passed from the person of the monarch to her ministers in parliament, emptying the theory of 'all the little historical or other justification' which it might once have possessed. ${ }^{80}$

This mattered because it was to the crown, as the temporal governor of the church, and as the guarantor of the external force of its laws under the reformation settlement, which ecclesiastical appeals went in the last resort. Such appeals, though they concerned legal formularies, often, in Phillimore's time, concerned questions regarding the doctrine and worship of the church. By Lord Brougham's Privy Council Appeals Act 1832, however, had transferred ecclesiastical appeals from the high court of delegates, the mixed court of civilians, common lawyers and (in theory) bishops to which appeals to Rome had been transferred at the Reformation, to the judicial committee of the privy council, a court composed, in theory at least, entirely of laymen and lawyers. ${ }^{81}$ This change, which was perceived fundamentally to alter the reformation settlement, was made by a parliament which was no longer Anglican in character and composition, ${ }^{82}$ without due consultation of the church, ${ }^{83}$ and, it was believed, without proper consideration of the right constitution of a court dealing with appeals relating to worship and doctrine. ${ }^{84}$ The scene was set for epic battles, in which Phillimore was to play a full and prominent role, regarding the spiritual authority of the final court of ecclesiastical appeal.

Woven into these battles was a rejection of traditional constitutional rationalisations of the role of the state in relation to the church. Traditionally, for example, parliament's actions would have been justified by the assertion that, in passing church legislation, it acted as the lay synod of the church. Phillimore, however, rejected this, arguing that in passing such legislation churchmen would act 'not as lay-Churchmen but as citizens ${ }^{35}$ Further, the very idea that a state which had embraced toleration

\footnotetext{
${ }^{79}$ Reports of the Proceedings of Church Congress (1876) 367.

${ }^{80}$ Ibid.

${ }^{81}$ The Act made no legal provision for the representation of bishops on the panel, though by convention the President of the Council was to appoint one or more bishops to act as assessors. The Church Discipline Act 1840, s.16, later provided that in appeals brought under it at least one bishop was to sit as a judge but that provision did not apply to appeals brought by other means.

82 The repeal of the Test and Corporation Acts in 1828, the Roman Catholic Relief Act 1829, and the Jews Relief Act 1857, admitted non-Anglicans to the full civic life of the nation not merely as an ad hoc concession, as had previously been the case, but as of right. Atheists too were eventually admitted in the 1880s after a long controversy in relation to Charles Bradlaugh. See (1881-82) L.R. 8 Q.B.D. 63, (1882-83) L.R. 8 App. Cas. 354, (1882-82) L.R. 11 Q.B.D. 1, (1883-84) L.R. 12 Q.B.D. 271 and (1884-85) L.R. 14 Q.B.D. 667.

${ }^{83}$ No formal mechanism for obtaining such consent was available before Convocations were revived in the 1850s, nor was it readily accepted that Convocations should be consulted. Certainly, this did not happen prior to the introduction of the Supreme Court of Judicature Bill 1873, nor the Public Worship Regulation Bill 1874 though in 1874 arguments were heard about the propriety or necessity of consulting Convocations. See Church and Parliament; or the Consent of the Church Necessary for the Establishment of Courts having Ecclesiastical Jurisdiction. By a Lawyer (New York, 1881) 5-6.

${ }^{84}$ The focus being on lax and immoral clergy. See Hutton, 'Reform of the Testamentary Jurisdiction'; Brougham at Parliamentary Debates, series 3, vol.111, col. 629, 3 June 1850 (House of Lords). ${ }^{85}$ Walter GF Phillimore, The Government of the Church in Relation to the State and the Laity (London, 1979$) 3$.
} 
could represent the church's laity was, he asserted, a fallacy ${ }^{86}$ Nor could Phillimore readily accept the argument that what the court of final ecclesiastical appeal did was to determine whether the doctrine or ceremonial complained of was legally consistent with the conditions upon which the clergy of the established church 'enjoyed the privileges and status which set them apart from other men' ${ }^{87} \mathrm{He}$ accepted that the state possessed the requisite authority to ensure that such conditions were met, ${ }^{88}$ but the line, between the interpretation of legal documents embodying doctrine, and the definition of doctrine itself, was not easily drawn. As another high churchmen explained, 'the mere fact that the formularies were established by statute, did not make their construction any the less a theological question' ${ }^{89}$ Further, the effects of the sentences imposed by it were both temporal, involving the loss of property and remuneration, and spiritual, involving the loss of spiritual office and the imposition of spiritual censures. Given this, he argued, the judicial committee of the privy council could never be a satisfactory court of final ecclesiastical appeal since it had received its mandate, not from the church, nor from the church and state acting in concert, but from a parliament and crown entirely lacking in spiritual authority. In his words, for 'a Court to rest its jurisdiction in spirituals upon such a commission would be as unreasonable as it would be for a Court sitting in England to rest its jurisdiction upon a commission from the Emperor of Germany'.$^{90}$

Phillimore's objections to the judicial committee of the privy council's role in hearing ecclesiastical appeals were absolute and enduring. No reforms, he said, would render it acceptable, ${ }^{91}$ or confer upon it the requisite spiritual authority. It could never be what was desired, a court which would 'have jurisdiction, in other words, a lawful commission and authority over the members of the Church'. ${ }^{92}$ Instead, he advocated for a spiritual provincial court of appeal, representing the archbishop and bishops of the province, from which there should be an appeal to the crown, in the form of an ordinary secular court. Such an appeal would lie only where the provincial court condemned a defendant in error or interfered with his property. ${ }^{93} \mathrm{He}$ called for such a provincial court to be free to depart from the judgments of the judicial committee of the privy council, in order to throw off entirely the lingering

\footnotetext{
86 Ibid.

${ }^{87}$ See e.g. 36 Saturday Review (1873), 37; also Lord Cranworth in support of his 1856 bill at Parliamentary Debates, series 3, vol.141, cols.1260-61, 21 April 1856 (House of Commons). For a contrasting emphasis upon the law as setting out spiritual standards see Bishop Blomfield of London at Parliamentary Debates, series 3 , vol.111, col.608, 3 June 1850 (House of Lords).

${ }^{88}$ Phillimore, The Government of the Church in Relation to the State. Also his evidence to the Royal Commission on Ecclesiastical Courts 1883, 1364, 1371, 1372, 1387 and 1399.

${ }^{89}$ W.F. Finlason, History, Constitution, and Character of the Judicial Committee, London, 1878, 113; also A.J. Beresford-Hope, 'An Ecclesiastical Olive Branch,' 15 Nineteenth Century (1884), 313.

${ }^{90}$ W.G.F. Phillimore, Ecclesiastical Courts and the Final Court of Appeal, London, 1879 (no page numbers).

${ }^{91}$ See e.g. evidence to the Royal Commission on Ecclesiastical Courts, 1883, 1344 and 1399. Also evidence to the 1906 Royal Commission, volume I, 5008-9.

92 Reports of the Proceedings of Church Congress (1883) 503.

${ }^{93}$ Evidence to the 1906 Royal Commission, 3579-81 and 3587.
} 
taint of its lack of spiritual authority. To hold otherwise would, he argued, fatally damage the authority of the proposed court. ${ }^{94}$

Ultimately, the church assembly's 1926 commission's report on ecclesiastical courts, of which Phillimore was a member, rejected the idea of a spiritual court of final appeal. It retained the final appeal to the crown, both as expressing the right of any citizen to approach the throne in pursuit of justice, and as a manifestation of the visitorial role of the crown in relation to the church. ${ }^{95}$ Though it was, the report asserted, 'in theory... conceivable that the Crown might make an Ecclesiastical Court the representative of its own supreme authority over all causes ecclesiastical and civil, in practice such a plan would be likely to confuse the issues so far as Churchmen are concerned, and to be unacceptable to the nation as a whole' ${ }^{96}$ Further, it argued, it was inexpedient that there should be two courts of final appeal, but the final court would have to deal with disciplinary cases other than doctrinal ones, and to do this it was most properly staffed by judges with a 'wide knowledge of civil and criminal law' ${ }^{97}$ In resolving the resulting tangle, however, it vindicated many of Phillimore's arguments.

The report's authors would have given to the crown's court the task of determining questions of fact and general law, while reserving questions of the doctrine, discipline or use of the church to be determined by a joint assembly of the bishops and archbishops of both provinces acting by majority decision. The advice of this assembly was to be binding on the court. ${ }^{98}$ To ensure that the spiritual authority of these arrangements could not be questioned, the legislation by which the proposed changes were to be secured was to receive the consent of both the convocations and the church assembly. ${ }^{99}$ Further, though the judges of the final court of appeal were to be appointed by the crown, and were to be men who held high judicial office, it was deemed expedient that they should declare themselves to be members of the Church of England. ${ }^{100}$ Only the decrees of the court were to be binding, reflecting the force of Phillimore's conviction that theological and liturgical thought were living things which had to have room to grow and develop. ${ }^{101}$ Finally, the court was to remit the case to an ecclesiastical court (with a spiritual mandate) for imposition of sentence. ${ }^{102}$ By these recommendations, the report's authors asserted, they:

... set forth and indicate the true character of the Court of Final Appeal. They recognise... that the duty of declaring the teaching and use of the Church belongs to its own spiritual authorities,

\footnotetext{
94 Ibid. 3588.

${ }^{95}$ Report of the Ecclesiastical Courts Commission 1926, para. 30.

96 Ibid. para. 31a

${ }^{97}$ Ibid. para. 31b.

${ }^{98}$ Ibid. para. 37.

${ }^{99}$ Ibid. para. 45.

${ }^{100}$ Ibid. para. 39.

${ }^{101}$ Ibid. para. 43.

102 Ibid. para. 43.
} 
and ... that the court is one commissioned by the Crown to hear appeals to the Crown for lack of justice in the Ecclesiastical Courts. ${ }^{103}$

Turning to matters of church government more generally, Phillimore also repeatedly argued for changes in the constitutional relationship between church and state. In private correspondence he asserted that he was 'opposed to Establishment in principle' and had 'often' been 'strongly' in favour of disestablishment. He could not, however, pledge himself to vote for or promote disestablishment at any particular time'. ${ }^{104}$ The Church was too closely woven into the fabric of national life for him to feel that disestablishment was possible and, more importantly, he was of the view that to make the attempt would be to bring 'strife and confusion where there is peace and good work and Christian life'. ${ }^{105}$ Thus, as the Liberal party adopted Welsh disestablishment, and as increasing numbers of his high church brothers in arms embraced the notion of English disestablishment, Phillimore's attentions focussed on securing some form of representative self-government for the church.

Unable to accept parliament as the lay synod of the church, increasingly alienated from the characterisation of the church as a national religious institution which comprehended all citizens of England, and keen to assert its spiritual identity as a body of believers, Phillimore had long called his fellow churchmen to recognise 'the true position of the laity in the Church' and to 'give them some voice in its government'. In 1879, he proclaimed:

Let there be side by side with the Convocation in each Province a house of - lay delegates, chosen by real Churchmen and communicants; let this house and the existing Convocation agree upon an arrangement as to their respective functions, so that no one body shall trespass upon the canonical rights of the other; and let the Provincial assemblies thus formed legislate for the wants of the Church. ${ }^{106}$

Such arrangements were, for him, a means of providing the church with vital autonomy, and of removing the obnoxious tyranny of the secular authority of parliament over matters which did not concern it. In his words:

It may be that Parliament will require some voice in the matter; but if so, let that voice be one of control and veto only, not entering into all the details of which it can understand nothing, but accepting as a rule in good faith what is propounded by the Church assemblies as for the advantage of the Church, and only interfering in very grave matters. ${ }^{107}$

Later, as he devoted himself to supporting the passage of the Church Assembly (Powers) Act 1919 through the house of lords. He explicitly tied the legislation to the spiritual vitality and autonomy of the church, to the impossibility of securing much needed church legislation through a parliament

\footnotetext{
${ }^{103}$ Ibid. para. 38 .

${ }^{104}$ Walter Phillimore to Lord Halifax, Borthwick: A4.212 (30 Sept. 1885). Also BL ADD MS 44279 fos. 219 221 (27 September 1891).

${ }^{105}$ Ibid.

${ }^{106}$ Phillimore, The Government of the Church in Relation to the State, 32.

${ }^{107}$ Ibid.
} 
choked with business and containing many individuals indifferent to the church's claims, and to the church's pressing imperative to respond to the spiritual needs of men who had come to faith in the trenches of the Great War. ${ }^{108}$

Just as he tolerated establishment, to which he objected in principle, for the practical good which it achieved, Phillimore accepted compromise in order to secure the legislation. So, for example, he respected Parliament's right of veto, saying that all that was wanted was 'to get through that legislation which the Church desires and of which Parliament at least does not disapprove'. ${ }^{109}$ Equally, while he plainly saw the church assembly as a form of representative government for the church as a spiritual body composed of believers, and not as a national religious institution in respect of which all citizens had certain legal rights, ${ }^{110}$ he nevertheless tied calls for the reform to the church's wider mission, asserting:

We offer you a scheme which enables that to be done which the Church wants, and the nation either wants or at least is content that the Church should have. And we want it for the best and the purest reasons, to promote the cause of religion and morals, and to enable that Church which the State has recognised as the Church of Christ to carry on its work. ${ }^{11}$

Phillimore supported the 1919 legislation even though he disliked some parts of the scheme, ${ }^{112}$ and he accepted that it was inevitable that church legislation would not 'be not altogether agreeable to some party or other in the church, particularly to extremists of any party'. He denounced the argument that this could under any circumstances justify the denial of the church's claims to self-determination. ${ }^{113}$

While Phillimore's resolute condemnation of the spiritual claims of the judicial committee of the privy council, and his desire for a spiritual court of final appeal, had bound him to his anglo-catholic brethren, his relationship with the more advanced elements within the English Church Union was increasingly fractious, and his willingness to compromise strained close personal relationships. As he told the house of lords:

... if there is a Sacerdotal party, I belong to it. ... I am at this moment the official representative of it. And I may tell you, my Lords, I have the greatest difficulty in persuading my friends not to oppose this Bill because they are not satisfied with it, because they think it gives apparently too much power to the laity, and because they do not like admitting, even as much as this Bill does, the relations of Parliament and the Church. ${ }^{114}$

\footnotetext{
108 Parliamentary Debates, series 5, vol. 35, cols. 63-65, 1 July 1919 (House of Lords).

${ }^{109}$ Ibid. col. 64.

${ }^{110}$ Ibid. cols. 69-71 - especially col. 71 where, on the franchise, he argued:' As citizens let them have their voice; as citizens they will have their voice; but as Church people they ought to have their voice only if... they are for the Church, not those who were on neither side...'

111 Ibid. col. 71.

${ }^{112}$ Parliamentary Debates, series 5, vol. 35, col. 473, 10 July 1919 (House of Lords) - particularly regarding the role of the ecclesiastical committee in parliament.

${ }^{113}$ Parliamentary Debates, series 5, vol. 35, col. 63-65, 1 July 1919 (House of Lords).

114 Ibid. col. 71.
} 
Phillimore was 'not advanced enough for the young bloods', 115 and indeed played an important role in thwarting their 'rash counsels'. ${ }^{116}$ Among his own ecclesiastical kind his was a moderating influence in a time of considerable constitutional and theological turbulence. His role in this respect was notable, even though he often failed to win the day. ${ }^{117}$ Here again, then, the picture of a high church zealot is replaced by a more nuanced portrait of a man willing to embrace compromise and practical accommodations in the pursuit of good aims, even where that alienated him from his fellows.

\section{Conclusion}

If, as Sugarman has suggested, legal biography 'sits ill' ${ }^{118}$ with modern concerns with significance, the choice of Walter Phillimore as a subject is an apparently bizarre one. Well-known in his own time he has faded into relative obscurity in succeeding generations. ${ }^{119}$ Nor, despite its comparatively recent moment in the judicial sun, was his dictum in Marshall v Graham particularly noteworthy, while the case itself was positively humdrum. Yet, through this essay it has been possible to explore the merits of legal biography and legal history as academic disciplines.

An exploration of Phillimore's life and judicial career strengthens and enriches our understanding of the religious and legal history of the nineteenth century. ${ }^{120}$ A consideration of his beliefs, context and activities as a notable advanced high churchman shed new light on the force and meaning of his famous dictum and enables us to broaden and deepen our understanding of the law and the context within which it developed, and to understand something of the mind-set and assumptions which are otherwise hidden from view. ${ }^{121}$ Legal biography in this respect supports the role which legal history has long played in helping the lawyer better to understand the law, and to understand the role which contingency and autonomy have played in its development and form. ${ }^{122}$ If one of the ways in

\footnotetext{
${ }^{115}$ LPL MS 2352 fol 162: Walter Phillimore to Athelstan Riley (June 28, 1925).

${ }^{116}$ The Guardian, 22 March 1929.

${ }^{117}$ Ibid.

${ }^{118}$ David Sugarman, 'From Legal Biography to Legal Life Writing: Broadening Conceptions of Legal History and Socio-legal Scholarship' 42(1) Journal of Law and Society (2015) 7, 16.

${ }^{119}$ Except as the originating author of a well-known international law book.

${ }^{120}$ For this argument - and for the role which biography plays in breaking down disciplinary barriers - see Robert I. Rotberg, 'Biography and Historiography: Mutual Evidential and Interdisciplinary Considerations' 40(3) Journal of Interdisciplinary History (2010) 305; R. Gwynedd Parry, 'Is Legal Biography Really Legal Scholarship?' 30(2) Legal Studies (2010) 208.

${ }^{121}$ A key function of legal biography - see John McEldowney, 'Challenges in Legal Bibliography: The Role of Biography in Legal History' 39 Irish Jurist (NS) 215.

${ }^{122}$ See e.g. Jim Phillips, 'Why Legal History Matters'; John McLaren, 'The Legal Historian, Masochist or Missionary - A Canadian's Reflections' 5 Legal Education Review (1994) 67; J.H. Baker, 'Why the History of English Law has not been Finished,'59(1) Cambridge Law Journal (2000) 62, 63; Raymond Cocks, 'History in Eclipse? The Role of the Past in Books on the English Legal System,' in Peter Birks (ed.), The Life of Law: Proceedings of the Tenth British Legal History Conference, London, 1991, 267; Reinhardt Zimmermann, Legal History: Does it Still Deserve a Place in the Curriculum? University of Cape Town: Inaugural Lecture, 6 May 1981; Russell Sandberg, 'The Time for Legal History: Some Reflections on Maitland and Milsom Fifty Years on' 180 Law and Justice - Christian Law Review (2018) 21.
} 
which legal history does this is to recognise the distinction between the stylised and selectively decontextualised identity of a case as legal precedent, and the fully contextualised and often radically different identity of a case as a historical event made up of a complex and contested web of facts, ${ }^{123}$ then one of the chief attributes of legal biography is to further our understanding of that historical event by developing our understanding of its human dimensions, and of 'the shifting interplay between agency, circumstance, and the material conditions prompting behaviour'. ${ }^{124}$ This is exemplified by the light shed on Phillimore's dictum by a full consideration of his character, beliefs and conduct as an avowed champion of the high church cause.

Above all, both legal biography and legal history, at their best, unsettle and challenge our assumptions about, and understanding of, the law. They are disruptive and subversive of settled orthodox understandings and received wisdom. ${ }^{125}$ Phillimore's dictum was a statement of political and theological belief. When the judges cited it in Aston Cantlow they were blind to this. A deeper knowledge, however, of Phillimore's life would have enabled them better to understand why, in 2003, the contention that a parochial church council might, for some purposes, be a public authority under the Human Rights Act seemed so problematic. The 'public authority' terminology of the domestic legislation caused no offence, but the language of art.34 of the European Convention of Human Rights, which speaks of governmental and non-governmental bodies, brought into play all of the old sensitivities of Phillimore and the high church revival. ${ }^{126}$ Judges are the product of their time, and the precedents with which they have endowed us sometimes have the power, whether acknowledged or not, to draw us into the web of assumptions and attitudes which shaped them. ${ }^{127}$

\footnotetext{
${ }^{123}$ See H Baker, 'Why the History of English Law has not been Finished', 77-78.

${ }^{124}$ Sugarman, 'Legal Biography', 8.

${ }^{125}$ Ibid. Also, Markus Dubber, 'Legal History as Legal Scholarship: Doctrinalism, Interdisciplinarity, and Critical Analysis of Law' 99-117 in Markus D. Dubber and Christopher Tomlins (eds.), The Oxford Handbook of Legal History, Oxford, 2018, at 101.

${ }^{126}$ See Augur Pearce, 'Aston Cantlow'; C Smith, 'A Very English Affair'.

127 Jim Phillips, 'Why Legal History Matters' 41 Victoria University of Wellington Law Review (2010) $293,316$.
} 